\title{
Penerjemahan Dialog Berimplikatur Dari Bahasa Inggris Ke Bahasa Indonesia Dalam Novel A Game Of Thrones
}

\author{
Lia Nurmalia \\ ABA BSI Jakarta \\ Email: lia.lnm@bsi.ac.id
}

\begin{abstract}
The objectives of this research are to know the types of implicature contained in the dialogue of A Game of Thrones, the strategy of translation used by the translator in translating the dialogue consisting implicature, and the equivalence deviation of translation. This research uses qualitative method which is comparative content analysis. The data is the dialog taken from A Game of Thrones. All the dialogues in the source text and in the target text are analyzed by using the comparative model. To analyze the types of implicature used Desilla's Theory. To analyze the strategy of translation used Molena and Albir and Newmark's theories. To analyze the equivalence used Koller's theory, and to analyze the deviation in translation used Newmark's theory. The risult of this research shows there are three types of implicature transference in translation. They are presevation about 129 (96.3\%), explicitation 2 (1.5\%), and modification 3 (2.3\%). It means most of implicature in the dialogues are transfered into the equivalent implicature. For strategy of translation, there are eleven strategies of translation used by the translator. They are transposition 50 (26.3\%), transference 11 (6\%), modulation 37 (19.4\%), cultural equivalence 16 (8.4\%), addition 7 (3.6\%), reduction 12 (6.3\%), literal translation 34 (18\%), explicitation $13(6.8 \%)$, implicitation $8(4.2 \%)$, calque $1(0.5 \%)$, and paraphrasing 1 $(0.5 \%)$. For equivalence can be concluded that the most of the dialogue reaches the equivalence. The equivalence of konotative 37 (28\%), denotative 38 (28.8\%), normatif text 2 (1.5\%), pragmatic 22 (16.7\%), and formal 33 (25\%). For the deviation in translation there are three types deviation. The first is the deviation caused by the grammatical differences 2 dialogues. The second is the deviation caused by modulation 1 dialogue, and the third is the deviation caused by reduction 1 dialogue.
\end{abstract}

Key Word: Translation, implicature, equivalence

\section{PENDAHULUAN}

Saat ini banyak karya sastra dunia berupa roman, novel, puisi yang diterjemahkan ke bahasa Indonesia. Terbukti dengan begitu mudah kita menemukan karya fiksi terjemahan di toko buku. Bahkan menurut Sayogi jumlah terjemahan karya fiksi lebih banyak daripada karya asli pengarang Indonesia (Frans Sayogi, 2014). Kemunculan terjemahan ini tentu disambut hangat oleh rakyat Indonesia karena dengan munculnya terjemahan maka rakyat Indonesia dapat dengan mudah memahami maksud cerita yang ada dalam karya fiksi asing dalam bahasa sendiri.

Namun, pada kenyataannya terjemahan itu sendiri menimbulkan permasalahan bagi pembaca karena terjemahan bahasa Indonesia sering membuat bingung pembacanya, bahkan terkadang pembaca baru dapat memahami maksud penulis setelah membaca teks sumbernya.

Seperti yang kita ketahui bahwa menerjemahakan teks sastra memerlukan perhatian lebih dibandingkan menerjemahkan teks lainnya. Penerjemah harus bekerja ekstra untuk menghasilkan terjemahan yang baik. Penerjemah harus memperhatikan banyak hal dalam menerjemahkan teks sastra khususnya novel, yaitu diantaranya unsur budaya, pilihan kata yang sangat beragam, gaya bahasa pengarang, dialog yang mengandungi implikatur dan sebagainya. Dari halhal tersebut yang akan dikaji dalam penelitian ini adalah dialog yang mengandungi implikatur.

Dalam menerjemahkan dialog yang mengandungi implikatur, penerjemah harus memahami betul maksud penutur, karena implikatur adalah maksud penutur yang tersembunyi di balik ujaran penutur (Grice, 1989) dengan kata lain penutur tidak mengungkapkan secara langsung apa yang dia maksud.

Dialog yang mengandungi implikatur biasanya juga terdapat dalam sebuah novel, cerita pendek dan lainlain. Peneliti memilih novel A Game of Thrones sebagai bahan kajian. Di dalam novel ini peneliti melihat banyak dialog yang mengandungi implikatur yang diungkapkan oleh para tokoh. Dalam novel ini, ada beberapa kasus menarik dalam penerjemahan dialog yang mengandungi implikatur, misalnya implikatur dalam TSu dialihkan ke dalam implikatur berbeda dalam TSa, Implikatur TSu dialihkan menjadi eksplisit dalam TSa. Seperti dialog yang mengandungi implikatur berikut ini:

$\begin{array}{cl}\text { TSu } & \text { : The steward came at once. "You } \\ \text { sent for me, my lord Hand?" } \\ \text { "Hand no longer," Ned told him. } \\ \text { TSa } \\ \begin{array}{c}\text { : Pengurus rumah tangga itu } \\ \text { langsung datang. "Anda }\end{array}\end{array}$


memanggil saya, Tuanku Tangan Kanan Raja?”

“Sudah tidak lagi," sahut Ned

Dialog di atas terjadi di menara King's Landing tempat Ned tinggal sebagai Tangan Kanan Raja. Ned baru saja kembali dari kamar Sang raja, Robert. Pada saat itu Ned memutuskan untuk mundur dari jabatan Tangan Kanan Raja karena Ned berbeda paham dengan Robert. Tiba-tiba seorang pelayan datang dan menanyakan apakah tadi Ned memanggilnya. Ned menjawab "Hand no longer". Jawaban Ned tidak secara langsung menjawab pertanyaan si pelayan tetapi tersembunyi dibalik ujaran tersebut, oleh karena itu dialog TSu adalah dialog yang mengangandungi implikatur. Implikatur TSu adalah Ned menegaskan kepada si pelayan, tidak perlu memanggilnya Lord Hand lagi karena Ned sudah mengundurkan diri. Dalam TSa diterjemahan menjadi "sudah tidak lagi”. Ungkapan "sudah tidak lagi” menunjukan Ned tidak secara langsung menjawab pertanyaan si pelayan maka dialog TSa juga mengandungi implikatur, namun implikatur TSa berbeda dengan TSu. Dalam TSa, implikaturnya adalah Ned menegaskan kepada si pelayan bahwa dia memang memanggil si pelayan tapi karena si pelayan lama tidak datang, akhirnya Ned marah dengan mengatakan "sudah tidak lagi". Pada kasus di atas implikatur TSu dialihkan ke dalam implikatur berbeda dalam TSa.

Pada terjemahan di atas penerjemah melakukan penghilangan kata Hand dan langsung menerjemahkan menjadi sudah tidak lagi, penghilangan yang dilakukan, ternyata berakibat pada perbedaan maksud pesan TSu dengan maksud TSa.

Melihat kasus penerjemahan dialog yang mengandungi implikatur dalam novel A Game of Thrones peneliti tertarik untuk mengkaji lebih dalam. peneliti memilih implikatur percakapan sebagai data penelitian. Implikatur percakapan adalah implikatur yang terdapat pada sebuah percakapan dalam situasi khusus (Grice, 1989) dimana pembaca harus paham betul runtutan pembicaraan dalam dialog tersebut. Selain itu, Implikatur percakapan juga lebih sering muncul daripada implikatur konvensional dalam novel $A$ Game of Thrones.

\section{METODOLOGI PENELITIAN}

Penelitian ini menggunakan pendekatan kualitatif dengan metode analisis isi model komparatif. Teknik pengumpulan data yang diterapkan adalah kajian dokumen. Dalam proses pengumpulan data, peneliti melakukan empat kegiatan. Pertama peneliti ini membaca novel sumber yaitu A Game of Thrones secara keseluruhan. Setelah membaca novel itu, peneliti melihat banyak dialog berimplikatur. Kedua peneliti ini fokus pada dialog berimplikatur dalam novel sumber dan novel sasaran. Dalam mengumpulkan data peneliti ini menggunakan teknik pengumpulan menggunakan kartu, yaitu dengan menuliskan nomor data, bab dalam novel, halaman dan paragraf, hal itu untuk memudahkan peneliti ketika ingin melihat konteks percakapan secara lengkap dalam novel. Ketiga, peneliti mereduksi data yang dianggap bukan merupakan dialog berimplikatur percakapan. Keempat, setelah terkumpul data yang berupa dialog berimplikatur percakapan, peneliti siap untuk mengkajinya. Data diperoleh dari novel $A$ Game of Thrones karya George R.R Martin sebagai novel sumber dan A Game of Thrones (Perebutan Takhta) yang diterjemahkan oleh Barokah Ruziati sebagai novel sasaran. Data yang dikumpulkan adalah semua dialog yang mengandung implikatur percakapan dalam dialog novel A Game of Thrones.

\section{HASIL DAN PEMBAHASAN}

Temuan penelitan yang akan dibahas pada bab ini mencakup jenis implikatur yang terkandung dalam dialog novel A Game of Thrones, strategi penerjemahan yang digunakan penerjemah, kesepadanan ungkapan TSu dan TSa pada novel $A$ Game of Thrones, serta penyimpangan dalam penerjemahan.

\subsection{Jenis implikatur yang terkandung dalam dialog novel A Game of Thrones.}

Setelah melakukan analisis, peneliti memperoleh 134 data berupa dialog berimplikatur percakapan dalam novel A Game of Thrones. Data itu dianalisis menggunakan teori jenis implikatur yang diproposisikan oleh Desilla yaitu ada tiga jenis implikatur dalam penerjemahan. Pertama, jenis preservasi (implikatur dialihkan ke dalam implikatur yang sama), kedua, jenis eksplisitasi (implikatur dialihkan menjadi eksplisit), ketiga, modifikasi (implikatur dialihkan ke dalam implikatur yang lain). Dalam penelitian ini, peneliti ini menemukan tiga jenis implikatur yang diterjemahkan dan akan ditunjukkan pada tabel berikut ini.

Tabel 1. analisis jenis penerjemahan implikatur dalam dialog novel A Game of Thrones

\begin{tabular}{llcc}
\hline No & $\begin{array}{c}\text { Jenis } \\
\text { implikatur }\end{array}$ & Jumlah & Persentase \\
\hline 1. & Preservasi & 129 & $96.3 \%$ \\
\hline 2. & Eksplisitasi & 2 & $1.5 \%$ \\
\hline 3. & Modifikasi & 3 & $2.2 \%$ \\
\hline & Total & 134 & $100 \%$ \\
\hline
\end{tabular}

Tabel 1 menunjukkan dialog berimplikatur dengan jenis preservasi sebanyak 129 atau 96.3\%, modifikasi sebanyak 2 atau $1.5 \%$ dan eskplisitasi sebanyak 3 atau 2.2\%. Dapat disimpulkan bahwa sebagian besar dialog berimplikatur dalam novel $A$ 
Game of Thrones dialihkan ke dalam implikatur yang sama. Berikut adalah contoh dialog berimplikatur jenis preservasi.

Dialog di bawah ini terjadi saat Ned sedang berada di hutan sakral untuk berdoa kepada Dewa lama, kemudian Catelyn datang menghampiri Ned dan mengabarkan berita bahwa Jon Aryyn meninggal.

\begin{tabular}{|c|c|}
\hline Catelyn & $\begin{array}{l}\text { : "I'm so sorry, my love. Jon Arryn } \\
\text { is dead" his eyes found hers. And } \\
\text { she could see how hard it took him, } \\
\text { as she had known it would... }\end{array}$ \\
\hline Ned & $\begin{array}{l}\text { : “Jon...” He said. "Is this news } \\
\text { certain?" }\end{array}$ \\
\hline Catelyn & $\begin{array}{l}\text { : "It was the king's seal, and the } \\
\text { letter is in Robert's own hand" }\end{array}$ \\
\hline Catelyn & $\begin{array}{l}\text { : “aku ikut berduka, sayangku. Jon } \\
\text { Aryyn meninggal.”Ned menatap } \\
\text { mata istrinya lurus-lurus, dan } \\
\text { Catelyn bisa melihat kabar itu } \\
\text { sangat mengguncangnya.Seperti } \\
\text { yang sudah diduga... }\end{array}$ \\
\hline Ned & $\begin{array}{l}\text { : “Jon...” Ned berkata."Kabar itu } \\
\text { sudah pasti?” }\end{array}$ \\
\hline Catelyn & : "Surat itu dibubuhi segel raja dan \\
\hline & dalam tulisan tangan Robert \\
\hline
\end{tabular}

Pada dialog di atas, bagian yang digaris bawah menunjukkan ungkapan yang mengandungi implikatur karena ungkapan tersebut tidak secara langsung menjawab pertanyaan Is this news certain? tetapi maksud penutur tersembunyi dibalik ujaran $\underline{I t}$ was the king's seal, and the letter is in Robert's own $\underline{\text { hand. Ujaran TSu diterjemahkan menjadi Surat itu }}$ dibubuhi segel raja dan dalam tulisan tangan Robert

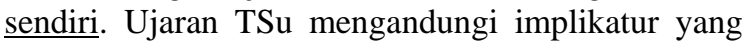
sama dalam TSa. Implikaturnya adalah Catelyn meyakinkan Robert bahwa kabar tersebut sudah pasti benar karena surat tersebut dibubuhi segel raja dan ditulis oleh raja. Dengan demikian dialog di atas mengandungi implikatur jenis preservasi karena TSa mengandungi implikatur yang sama dengan TSu. Berikut adalah contoh dialog berimplikatur jenis eksplisitasi.

Dialog di bawah ini terjadi saat Ned dipanggil oleh raja Robert ke ruangannya. Pada saat itu Ned baru saja pulih dari cedera akibat diserang Jaime Lannister. Sesampainya di ruangan raja Ned ditawari wine oleh raja.

Robert : "No matter," the king said gruffly. "Some wine? From the Arbor. A good vintage."

Ned : "A small cup," Ned said. "My head is still heavy from the milk of the poppy."
Robert : “Tak masalah,” sergah sang raja. "Mau anggur? Dari punjung. Anggur tua yang bagus."

Ned : "Sedikit saja," sahut Ned. "Kepalaku masih berat setelah minum sari bunga opium.”

Dialog TSu di atas mengandungi implikatur karena ungkapan yang digaris bawah menunjukan Ned tidak secara langsung menjawab tawaran Robert melainkan tersembunyi dibalik ujaran "A small cup". Dari ujaran tersebut terlihat, untuk menghargai raja Ned menerima tawarannya setengah hati tapi menggunakan bahasa yang halus yaitu " $\underline{A}$ small cup". Namun dalam TSa ungkapan "A small cup" diterjemahkan menjadi "Sedikit saja,". Ujaran "Sedikit saja," terlihat sudah tidak mengandungi implikatur karena dalam TSa Ned secara langsung menerima tawaran raja tapi Ned ingin minum sedikit saja. Oleh karena itu dialog di atas dikategorikan dialog yang mengandungi implikatur jenis eksplisitasi karena dialog yang mengandungi implikatur TSu diterjemahkan menjadi eksplisit dalam TSa. Berikut adalah contoh dialog berimplikatur jenis modifikasi.

Dialog di bawah ini terjadi di menara King's Landing tempat Ned tinggal sebagai Tangan Kanan Raja. Ned baru saja kembali dari kamar Sang raja, Robert. Pada saat itu Ned memutuskan untuk mundur dari jabatan Tangan Kanan Raja karena Ned berbeda paham dengan Robert. Tiba-tiba seorang pelayan datang dan menanyakan apakah tadi Ned memanggilnya.

\begin{tabular}{|c|c|}
\hline Steward & $\begin{array}{l}\text { : The steward came at once. "You } \\
\text { sent for me, my lord Hand?" }\end{array}$ \\
\hline Ned & : "Hand no longer," Ned told him. \\
\hline & $\begin{array}{l}\text { "The king and I have quarreled. } \\
\text { We shall be returning to } \\
\text { Winterfell." }\end{array}$ \\
\hline
\end{tabular}

Steward : Pengurus rumah tangga itu langsung datang. "Anda memanggil saya, Tuanku Tangan Kanan Raja?”

Ned : "Sudah tidak lagi," sahut Ned, "Aku bertengkar dengan Raja. Kita akan kembali ke Winterfell.”

Dialog TSu dan TSa di atas mengandungi implikatur karena ungkapan yang digarisbawahi menunjukan Ned tidak secara langsung menjawab pertanyaan si pelayan tetapi apa yang Ned maksud tersembunyi di balik ujaran yang Ned ujarkan. Ungkapan TSu "Hand no longer," menunjukan bahwa Ned bermaksud mengatakan kepada si pelayan tidak perlu memanggilnya Tangan kanan raja lagi karena Ned sudah mengundurkan diri. Ungkapn TSu diterjemahkan menjadi "Sudah tidak lagi,". Ungkapan dalam TSa menunjukan Ned marah 
kepada si pelayan karena Ned memanggilnya tetapi si pelayan lama tidak muncul. Dengan demikian implikatur TSu dialihkan ke dalam implikatur berbeda dalam TSa. Sehingga dialog di atas dikategorikan dialog yang mengandungi implikatur jenis modifikasi.

\subsection{Strategi penerjemahan yang digunakan penerjemah}

Setelah dilakukan analisis, terdapat 11 strategi penerjemahan yang digunakan penerjemah dalam menerjemahkan 134 dialog berimplikatur dalam novel A Game of Thrones. Pada 134 dialog ada yang diterjemahkan menggunakan lebih dari satu strategi penerjemahan. Dari 134 dialog ditemukan 190 data untuk di analisis strategi penerjemahannya. Hasil penelitian akan dideskripsikan melalui tabel berikut ini.

Tabel 2 Strategi penerjemahan

\begin{tabular}{lcc}
\hline \multicolumn{1}{c}{ Strategi Penerjemahan } & Jumlah & Persentase \\
\hline Transposisi & 50 & $26.3 \%$ \\
\hline Transferensi & 11 & $6 \%$ \\
\hline Modulasi & 37 & $19.4 \%$ \\
\hline Penjelasan Tambahan & 7 & $3.6 \%$ \\
\hline Pengurangan & 12 & $6.3 \%$ \\
\hline Padanan Budaya & 16 & $8.4 \%$ \\
\hline Penerjemahan Literal & 34 & $18 \%$ \\
\hline Implisitasi & 8 & $4.2 \%$ \\
\hline Eksplisitasi & 13 & $6.8 \%$ \\
\hline Calque & 1 & $0.5 \%$ \\
\hline Parafrasa & 1 & $0.5 \%$ \\
\hline & 190 & $100 \%$ \\
\hline
\end{tabular}

Tabel 2 menunjukkan penggunaan strategi transposisi sebanyak 50 kali, transfer 11 kali, modulasi 37 kali, penjelasan tambahan $7 \mathrm{kali}$, penerjemahan dengan pengurangan 12 kali, padanan budaya 16 kali, penerjemahan literal 34 kali, implisitasi 8 kali, eksplisitasi 13 kali, calque 1 kali dan parafrasa 1 kali. Startegi yang paling sering dilakukan oleh penerjemah adalah transposisi kemudian modulasi, penerjemahan literal, padanan budaya, eksplisitasi, penerjemahan dengan pengurangan, penjelasan tambahan, implisitasi, transfer, kalki dan parafarasa.

Berikut contoh dialog berimplikatur, yang diterjemahkan dengan strategi yang paling sering digunkan.

Tabel 3 Contoh analisis strategi penerjemah

\begin{tabular}{ccccc}
\hline Strategi & TSu & TSa & Analisis \\
& & & \\
\hline Transposisi & " $\underline{\text { His back }}$ & "Punggun & Ungkapan yang \\
\hline
\end{tabular}

\begin{tabular}{|c|c|c|c|}
\hline & $\begin{array}{l}\frac{\text { is broken }}{\text { little one. }} \\
\begin{array}{l}\text { Tyrion told } \\
\text { her }\end{array}\end{array}$ & $\begin{array}{l}\text { gnya } \\
\text { patah, } \\
\text { Nak,” } \\
\text { Tyrion } \\
\text { memberita } \\
\text { hu }\end{array}$ & $\begin{array}{l}\text { mengandungi } \\
\text { implikatur di } \\
\text { atas } \\
\text { diterjemahkan } \\
\text { menggunakan } \\
\text { strategi } \\
\text { transposisi } \\
\text { karena terjadi } \\
\text { pergeseran } \\
\text { antara TSu ke } \\
\text { TSa yaitu } \\
\text { kalimat dalam } \\
\text { TSu menjadi } \\
\text { klausa dalam } \\
\text { TSa }\end{array}$ \\
\hline Modulasi & $\begin{array}{l}\text { "It was the } \\
\text { king's seal, } \\
\text { and the } \\
\text { letter is in } \\
\text { Robert's } \\
\text { own hand" }\end{array}$ & $\begin{array}{l}\text { "Surat itu } \\
\text { dibubuhi } \\
\text { segel raja } \\
\text { dan dalam } \\
\frac{\text { tulisan }}{\text { tangan }} \\
\text { Robert } \\
\text { sendiri." }\end{array}$ & $\begin{array}{l}\text { Penerjemah } \\
\text { mempunyasi } \\
\text { sudut pandang } \\
\text { berbeda dalam } \\
\text { menjelaskan } \\
\text { kalimat TSu } \\
\text { menjadi lebih } \\
\text { sederhana } \\
\end{array}$ \\
\hline $\begin{array}{l}\text { Penerjemah } \\
\text { an Literal }\end{array}$ & $\begin{array}{ll}\text { "I am } & \text { told } \\
\text { you } & \text { can } \\
\text { read." } & \end{array}$ & $\begin{array}{l}\text { “Aku } \\
\underline{\text { diberitahu }} \\
\text { kau bisa } \\
\underline{\text { membaca. }} \\
\text { ” }\end{array}$ & $\begin{array}{l}\text { Kalimat pasif } \\
\text { dalam TSu } \\
\text { diterjemahkan } \\
\text { menjadi } \\
\text { kalimat pasif } \\
\text { dalam TSa } \\
\end{array}$ \\
\hline
\end{tabular}

\subsection{Kesepadanan penerjemahan dialog berimplikatur dalam ungkapan TSu ke TSa pada novel A Game of Thrones}

Setelah dilakukan analisis, diperoleh 134 dialog berimplikatur. Dari 134 dialog itu sebagian besar dialog mencapai kesepadanan. Namun, ada 2 dialog yang tidak mencapai kesepadanan. Jadi ada 132 dialog yang mencapai kesepadanan. Berdasarkan teori yang diproposisikan oleh Koller ada 5 tingkat kesepadanan yang dicapai yaitu kesepadanan denotatif, konotatif, teks normatif, pragmatik, dan formal. Berikut tabel analisis kesepadan ungkapan TSu ke TSa dalam novel A Game of Thrones.

Tabel 4 kesepadanan penerjemahan

\begin{tabular}{cccc}
\hline No & Kesepadanan & Jumlah & Persentasi \\
\hline 1. & Denotatif & 38 & $28.8 \%$ \\
\hline 2. & Konotatif & 37 & $28 \%$ \\
\hline 3. & Teks normatif & 2 & $1.5 \%$ \\
\hline 4. & Pragmatik & 22 & $16.7 \%$ \\
\hline 5. & Formal & 33 & $25 \%$ \\
\hline & Total & 132 & $100 \%$ \\
\hline
\end{tabular}

Tabel di atas menunjukkan sebagian besar dialog berimplikatur mencapai kesepadanan denotatif yaitu sebanyak 38 atau 28.8\%, kemudian kesepadanan konotatif sebanyak 37 atau 28\%, kesepadanan formal sebanyak 33 atau 25\%, kesepadanan pragmatik sebanyak 22 atau $16.7 \%$ dan kesepadanan teks normatif sebanyak 2 atau 1.5\%. Berikut contoh analisis kesepadanan dialog berimplikatur dalam novel A Game of Thrones. 
Tabel 5 Analisis Kesepadanan

\begin{tabular}{|c|c|c|c|}
\hline $\begin{array}{c}\text { Kesepadan } \\
\text { an }\end{array}$ & TSu & TSa & Analisis \\
\hline Denotatif & $\begin{array}{l}\text { "He was a } \\
\text { wildling," }\end{array}$ & $\begin{array}{l}\text { “dia orang } \\
\text { wildiling," }\end{array}$ & $\begin{array}{l}\text { diterjemahkan } \\
\text { dengan } \\
\text { menggunakan } \\
\text { istilah yang } \\
\text { sama dengan } \\
\text { TSu demi } \\
\text { menjaga } \\
\text { kesepadanan } \\
\text { istilah tersebut }\end{array}$ \\
\hline Konotatif & $\begin{array}{l}\text { "He will if } \\
\text { Robert } \\
\text { commends } \\
\text { it," }\end{array}$ & $\begin{array}{l}\text { "Dia akan } \\
\text { pergi jika } \\
\text { Robert } \\
\text { memberi } \\
\text { perintah," }\end{array}$ & $\begin{array}{l}\text { penerjemah } \\
\text { mengeksplisit } \\
\text { kan kata will } \\
\text { menjadi kata } \\
\text { akan pergi. } \\
\text { Eksplisitasi } \\
\text { tersebut } \\
\text { sebenarnya } \\
\text { tetap } \\
\text { menyajikan } \\
\text { pesan yang } \\
\text { sepadan. }\end{array}$ \\
\hline $\begin{array}{l}\text { Teks } \\
\text { normatif }\end{array}$ & $\begin{array}{l}\text { "Septa } \\
\text { Mordane } \\
\frac{\text { says }}{\text { most... }} \\
\frac{\text { most }}{\text { highborn }} \\
\frac{\text { girls have }}{\text { their }} \\
\text { flowering } \\
\text { at twelve } \\
\text { or } \\
\text { thirteen." }\end{array}$ & $\begin{array}{l}\underline{\text { Kata }} \\
\text { Septa } \\
\text { Mordane } \\
\text { kebanyaka } \\
\underline{\text { n... }} \\
\text { kebanyaka } \\
\text { n gadis } \\
\text { bangsawa } \\
\underline{n} \text { mencapai } \\
\text { kedewasaa } \\
\underline{\text { n pada }} \\
\text { usia dua } \\
\text { belas atau } \\
\text { tiga } \\
\text { belas." }\end{array}$ & $\begin{array}{l}\text { TSa } \\
\text { diterjemahkan } \\
\text { tidak terlalu } \\
\text { formal karena } \\
\text { teks yang } \\
\text { diterjemahkan } \\
\text { adalah teks } \\
\text { sastra bukan } \\
\text { teks ilmiah }\end{array}$ \\
\hline Pragmatik & $\begin{array}{l}\text { "She has } \\
\text { had her } \\
\text { blood. She } \\
\text { is old } \\
\text { enough for } \\
\text { the Khal." }\end{array}$ & 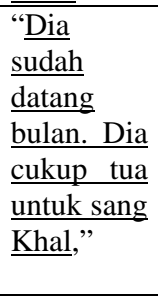 & $\begin{array}{l}\text { penerjemah } \\
\text { menyesuaikan } \\
\text { istilah yang } \\
\text { biasa } \\
\text { digunakan di } \\
\text { BSa, Blood } \\
\text { menjadi } \\
\text { datang bulan. }\end{array}$ \\
\hline Formal & $\begin{array}{l}: \text { "If you } \\
\text { walk } \\
\text { slowly," }\end{array}$ & $\begin{array}{l}\text { "Kalau } \\
\text { kau jalan } \\
\text { pelan- } \\
\text { pelan," }\end{array}$ & $\begin{array}{l}\text { TSa } \\
\text { diterjemahkan } \\
\text { sesuai dengan } \\
\text { estetika TSu, } \\
\text { struktur TSu } \\
\text { teralihkan } \\
\text { secara sepadan } \\
\text { dalam TSa. }\end{array}$ \\
\hline
\end{tabular}

\subsection{Penyimpangan dalam Penerjemahan dialog berimplikatur}

Dalam penelitian ini ditemukan tiga jenis penyimpangan penerjemahan dari lima jenis penyimpangan penerjemahan menurut Newmark. Ketiga jenis penyimpangan itu adalah ketidaksepadanan gramatikal, adanya kata yang tidak diterjemahkan, dan perbedaan sudut pandang penerjemah. Berikut adalah contoh analisis penyimpangan dalam penerjemahan.

Tabel 6 Analisis Penyimpangan Penerjemahan

\begin{tabular}{|c|c|c|c|}
\hline $\begin{array}{l}\text { Penyimpan } \\
\text { gan }\end{array}$ & $\mathrm{TSu}$ & TSa & Analisis \\
\hline $\begin{array}{l}\text { ketidaksepa } \\
\text { danan } \\
\text { gramatikal }\end{array}$ & $\begin{array}{l}\text { Just } \\
\text { before } \\
\text { he } \\
\text { closed } \\
\frac{\text { his }}{\text { eyes }} \\
\text { for the } \\
\text { last } \\
\text { time, }\end{array}$ & $\begin{array}{l}\frac{\text { Sesaat }}{\text { sebelum }} \\
\text { memejamk } \\
\text { an mata } \\
\text { untuk } \\
\text { terakhir } \\
\text { kali, }\end{array}$ & $\begin{array}{l}\text { penerjemah } \\
\text { mengabaikan } \\
\text { maksud TSu, } \\
\text { sehingga } \\
\text { mengakibatkan } \\
\text { penyimpangan } \\
\text { penerjemahan } \\
\text { dan membuat } \\
\text { TSa bermakna } \\
\text { sebaliknya dari } \\
\text { TSu }\end{array}$ \\
\hline $\begin{array}{l}\text { kata yang } \\
\text { tidak } \\
\text { diterjemahk } \\
\text { an }\end{array}$ & $\begin{array}{l}\text { " } \underline{\text { Hand }} \\
\text { no } \\
\text { longer, }\end{array}$ & $\begin{array}{l}\text { "Sudah } \\
\text { tidak lagi," }\end{array}$ & $\begin{array}{l}\text { Dalam kasus ini } \\
\text { penerjemah } \\
\text { tidak } \\
\text { menerjemahkan } \\
\text { kata Hand, } \\
\text { sehingga } \\
\text { penyimpangan } \\
\text { ini disebabkan } \\
\text { oleh adanya kata } \\
\text { yang tidak } \\
\text { diterjemahkan }\end{array}$ \\
\hline $\begin{array}{l}\text { perbedaan } \\
\text { sudut } \\
\text { pandang }\end{array}$ & 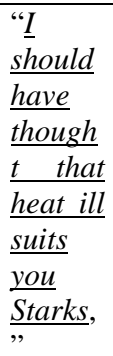 & $\begin{array}{l}\text { "Padahal } \\
\text { kukira } \\
\text { panas tidak } \\
\text { cocok } \\
\text { untuk Klan } \\
\text { Stark." }\end{array}$ & $\begin{array}{l}\text { Dalam kasus ini } \\
\text { penerjemah } \\
\text { menggunakan } \\
\text { strategi } \\
\text { modulasi, tetapi } \\
\text { berakibat pada } \\
\text { penyimpangan } \\
\text { makna. }\end{array}$ \\
\hline
\end{tabular}

\section{KESIMPULAN}

Ada empat subfokus penelitian yang dikaji dalam penelitian ini, pertama jenis implikatur yang terkandung dalam dialog berimplikatur dalam novel A Game of Thrones. Analisis jenis implikatur ini menggunakan teori yang diproposisikan oleh Desilla yaitu ada tiga jenis penerjemahan implikatur, preservasi (implikatur dialihkan ke dalam implikatur yang sama), eksplisitasi (implikatur dialihkan menjadi eksplisit), dan modifikasi (implikatur dialihkan ke dalam implikatur yang lain).

Dalam penelitian ditemukan tiga jenis pengalihan implikatur dalam penerjemahan. Pertama jenis preservasi sebanyak 129 (96.3\%), kedua jenis eksplisitasi sebanyak 2 (1.5\%), ketiga jenis modifikasi sebanyak 3 (2.2\%). Dengan demikian dapat disimpulkan bahwa sebagian besar implikatur dalam dialog novel A Game of Thrones dialihkan ke dalam implikatur yang sepadan.

Subfokus kedua yaitu strategi penerjemahan yang digunakan penerjemah dalam menerjemahkan dialog 
yang mengandungi impikatur pada novel A Game of Thrones. Untuk menganalisis strategi penerjemahan, peneliti ini menggunakan teori yang sebagian diambil dari Newmark dan Molena dan Albir. Dari 13 strategi penerjemahan, peneliti menemukan 11 strategi penerjemahan yang digunakan penerjemah dalam menerjemahkan dialog berimplikatur. Pada 134 dialog ada yang diterjemahkan menggunakan lebih dari satu strategi penerjemahan. Dari 134 dialog ditemukan 190 data untuk di analisis strategi penerjemahannya. Untuk strategi transposisi sebanyak 50 kali (26.3\%), untuk strategi transferensi sebanyak 11 kali (6\%), untuk strategi modulasi sebanyak 37 kali (19.4\%), untuk strategi penjelasan tambahan sebanyak 7 kali (3.6\%), untuk strategi penerjemahan dengan pengurangan sebanyak 12 kali (6.3\%), untuk strategi padanan budaya sebanyak 16 kali (8.4\%), untuk strategi penerjemahan literal sebanyak 34 kali (18\%), untuk strategi implisitasi sebanyak 8 kali (4.2\%), untuk strategi eksplisitasi sebanyak 13 kali (6.8\%), untuk strategi calque sebanyak 1 kali (0.5\%), untuk strategi parafrasa sebanyak 1 kali (0.5\%).

Subfokus ketiga adalah kesepadanan antara dialog TSu dan TSa yang termati berkat teori yang diproposisikan oleh Koller. Dalam penelitian ini ditemukan 5 jenis kesepadanan yaitu kesepadanan denotatif sebanyak 38 dialog (28.8\%), kesepadanan konotatif sebanyak 37 dialog (28\%), kesepadanan teks normatif sebanyak 2 dialog (1.5\%), kesepadanan pragmatik sebanyak 22 (16.7\%), dan kesepadanan formal sebanyak 33 (25\%).

Subfokus keempat yaitu penyimpangan dalam penerjemahan yang dianalisis menggunakan teori yang diproposisikan oleh Newmark. Dari lima jenis penyimpangan dalam penerjemahan, hanya ditemukan tiga jenis penyimpangan dalam penelitian ini. Pertama penyimpangan penerjemahan yang diakibatkan oleh ketidaksepadanan gramatikal sebanyak 2 dialog, adanya kata yang tidak diterjemahkan sebanyak 1 dialog, dan perbedaan sudut pandang penerjemah sebanyak 1 dialog. Berdasarkan penjabaran di atas dapat disimpulkan bahwa sebagian besar dialog berimplikatur diterjemahkan secara sepadan 98.5\% dan hanya $1.5 \%$ dialog yang tidak sepadan.

\section{REFERENSI}

Abdellah. A. S. (2002). "The Translator's Dilemma Implicatures and the role of the translator." Translation Journal. Vol 6, No. 3, July. Online, available: http://accurapid.com/journal/21novice.htm

Black, Elizabeth. 2006. Pragmatic Stylistic. Edinburgh: Edinburgh University Press.

Catford, J.C.1996. A Linguistic Theory of translation. London: Oxford University Press.
Grice, H.P.1975. "Logic and Conversation” Syntax and Semantics, Speech Act, 3. New York: Academic Press.

Emzir. 2009. Metodologi Penelitian Pendidikan, Kuantitaif dan Kualitatif. Jakarta: Raja Grafindo Persada.

Hansen, Maj-Britt Mosegaard. 2008. Particles at the Semantics/ Pragmatics Interface: Synchronic and Diachronic Issue. UK: The University of Manchester.

Hasan, Alwi. 2003.Tata Bahasa Baku Bahasa Indonesia. Jakarta: Balai Pustaka.

Hatim, Basil dan Jeremy munday. 2004. Translation: An Advanced Resource Book. New York: Routledge.

H.B. Sutopo. 2002 .Metodologi Penelitian Kualitatif. Surakata: UNS Press.

Hoed, Benny Hoedoro. 2006. Penerjemahan dan Kebudayaan. Bandung: Pustaka Jaya.

Jaszcolt. K.M. 2001 Semantics and Pragmatics. New York: Pearson Education.

Laharomi, Zahra Hassani (2013) “Conversational Implicatures in English Plays and Their Persian Translations: A Norm-governed Study." International Journal of Applied Linguistics \& English Literature ISSN 2200-3592 (Print), ISSN 2200-3452 (Online) Vol. 2 No. 5; September 2013

Landers, Clifford E. 2001. Literary Translation: A Practical Guide. Great Britain: Cromwell Press Ltd.

Leech, Geoffrey N. 1983. Principles of Pragmatics. London and New York: Gramedia.

Machali, Rochayah. 2000. Pedoman Umum Bagi Penerjemah. Jakarta: Pt.Grasindo.

Moeliono, Anton. M. 2007. Kamus Besar Bahasa Indonesia. Jakarta: Balai Pustaka

Moleong, Lexy J. 2012. Metodologi Penelitian Kualitatif. Bandung:PT. Remaja Rosdakarya.

Mujiyono, Wiryationo. 1996. Implikatur percakapan Anak Usia Sekolah Dasar. Malang: IKIP Malang.

Munday, Jeremy. 2008. Introducing Translation Studies: Theories and Application. London dan New York: Routlege 
Nababan, Mangatur, dkk. 2012. Pengembangan Model Penilaian Kualitas Terjemahan: Kajian Linguistik dan Sastra. Vol.24

Nadar, F.X. 2009. Pragmatik dan Penelitian Pragmatik. Yogyakarta:Graha Ilmu

Newmark, Peter. 1996. About Translation Multilingual Matters Great Britain: The Longdunn Press Ltd.

Nida, Eugene A dan Charles R. Taber. 1982. The Theory and Practice of Translation. Helps for Translator Den Haag: Brill.

Sayogi, Frans. 2014. Teori dan Praktik Penerjemahan. Tangerang Selatan: Transpustaka.

Yule, George. 1996. Pragmatics. Oxford: Oxford University Press. 